\title{
The Highest Rate of Public Trust IN JUDICIARY IN TWENTY YEARS IN LithuANiA: TREND OR COINCIDENCE? *
}

\author{
Julija Kiršiené ${ }^{* *} \&$ Edita Gruodyte $\dot{e}^{* * *}$ \\ Vytautas Magnus University, Lithuania \\ Julija.kirsiene@vdu.lt;Edita.gruodyte@vdu.lt
}

KIRŠIENĖ, Julija; GRUODYTĖ, Edita. The Highest Rate of Public Trust in Judiciary in Twenty Years in Lithuania: Trend or Coincidence? International and Comparative Law Review, 2019, vol. 19, no. 1, pp. 125-145. DOI: 10.2478/iclr2019-0004

\begin{abstract}
Summary: Until 2018 public trust in judiciary in Lithuania was more negative than positive. Results of 2018 are exceptional as show the highest rates of trust in 22 years. The aim of this article - to find out if these results are coincidence or indicate increase of public trust in judiciary. To explore this issue this paper will analyze the concept and dynamics of trust in judiciary, possible measures of professionalism and examine how these aspects are reflected in Lithuanian judiciary. Our research reveals two main reasons for the improved trust in the judiciary: good performance including use of technology and greater transparency that provides the public greater access to information about the justice system.
\end{abstract}

Keywords: judiciary, Lithuania, democracy, public trust, efficiency, quality, professionalism.

* This research was funded by the European Social Fund according to the activity 'Improvement of researchers' qualification by implementing world-class R\&D projects of Measure No. 09.3.3-LMT-K-712.

** She is Vice-Rector for Research at Vytautas Magnus University. Also, she is a tenure professor at Department of Private Law. She is a member of several public bodies including Judicial Court of Honor, Management Board of European Union Fundamental Rights Agency (FRA). She is an expert of Research Council of Lithuania and chairperson of the board of Kaunas Science and Technology Park. Professor Kiršienè is a co-author of several textbooks, and member of editorial boards of two internationally recognized scientific journals. Her research interests contract law, tort law, legal ethics and professionalism, human rights.

*** She is tenure professor in public law department and vice-dean for research at Faculty of Law. She has more than 20 years' experience of diverse legal work (both as a lawyer in various business companies and as attorney) and in scientific research and academic work. Gruodyte is the author and co-author of several books, author of more than 40 scientific articles in various national and international scientific journals and books. Specializes in criminal law (including national, European, business crimes), legal ethics and certain aspects of human rights. She is an expert in various national and international organizations has some legislative drafting experience. 


\section{Introduction}

Public opinion about judiciary in Lithuania has been measured for more than 20 years. The spring 2018 results show the highest rates of trust in in the Lithuanian judiciary in 22 years. Moreover, during all this period, respective rate of distrust has always been considerably higher than rate of confidence. Only recently has the score of positive attitudes overweighed negative. It should be noted that trust in judiciary is inseparably interconnected with trust in courts, because judiciary is an essential actor in the justice system, however performance, efficiency and especially transparency of this system depends also on infrastructure, public communication policy and other administrative measures.

Indeed, according to Benjamin Disraeli, the 19th century British Prime Minister, "there are three kinds of lies: lies, damned lies, and statistics". If the abovementioned survey results do not lie, the goal of this article is to analyze the main reasons of growing confidence in judiciary, which as analyzed below, is a very complex phenomenon. Our research reveals two main reasons for the improved trust in the judiciary: good performance including use of technology and greater transparency that provides the public greater access to information about the justice system. These improvements are critical components of improving the functioning of Lithuania as an emerging democracy.

The public trust is a crucial binding concept in the effective operation of the justice system. A publicly supported judiciary ensures voluntary acceptance of judicial decisions. Trust in the judiciary is still not fairly emphasized and often justice policy decisions are based upon an assumed "public concern" on various matters of justice, in the absence of any reliable scientific measure of confidence. Measuring confidence in judiciary offers important information to policy makers about the level of confidence in the justice system.

Because the empirical research on the judiciary is quite rare $^{2}$, for analysis of above mentioned dimensions, especially dimension of good performance, we used not only available quantitative information about quality and efficiency of

1 MARTIN, Gary. There Are Three Kinds of Lies: Lies, Damned Lies, and Statistics - the Meaning and Origin of This Phrase. [online]. Available at: <https://www.phrases.org.uk/meanings/lies-damned-lies-and-statistics.html.> Accessed: 16.12.2018.

2 BÜHLMANN, Mark, KUNZ, Ruth. Confidence in the Judiciary: Comparing the Independence and Legitimacy of Judicial Systems. West European Politics, 2011, vol. 34, no. 2, p. 318 . 
courts from EU scoreboard ${ }^{3}$ and other assessments ${ }^{4}$ but also results of two resent empirical studies conducted at Vytautas Magnus University Faculty of Law ${ }^{5}$.

3 THE EUROPEAN COMMISSION. The 2018 EU justice scoreboard, Communication from the Commission to the European Parliament, the Council, the European Central Bank, the European Economic and Social Committee and the Committee of the Regions. [online]. Available at: // <https://ec.europa.eu/info/sites/info/files/justice_scoreboard_2018_en.pdf> Accessed: 10.10.2018.

4 See THE EUROPEAN COMMISSION FOR THE EFFICIENCY OF JUSTICE. European judicial system. Efficiency and quality of justice. [online]. Available at:

$<\mathrm{https} / / / \mathrm{rm}$.coe.int/european-judicial-systems-efficiency-and-quality-of-justice-cepejstud/1680788228> Accessed: 07.05.2019. THE EUROPEAN COMMISSION FOR THE EFFICIENCY OF JUSTICE. Guidelines on how to drive change towards cyberjustice. Stocktaking of tools deployed and summary of good practices. [online]. Available at: $<\mathrm{https}$ ://edoc. coe.int/en/efficiency-of-justice/7501-guidelines-on-how-to-drive-change-towards-cyberjustice-stock-taking-of-tools-deployed-and-summary-of-good-practices.html> Accessed 10.07.2018.

5 1) In February - May of 2018 the authors of the article prepared and distributed web questionnaire (with big help of national court administration) to Lithuanian judges and court personnel (judge assistants and secretaries) aiming to find out how technological progress (IT) affects court activities, well-being and the challenges they face. 96 respondents answered the questionnaire. Major part of respondents - 44\% - judge assistants, 19 $\%$ - judges, remaining part - court secretaries; respondents participated from all categories and levels of courts but dominated the ones from the courts of 1st (district) and second instances (regional). The questionnaire was anonymous, with 9 IT content questions (with provided statements and possibility to add additional answers) and 5-person related questions (age, court, position, work experience, case categories) were prepared. 2) In 2012-2014 scientists from Vytautas Magnus University Law faculty successfully implemented national project financed by Lithuanian Scientific Board "The Conception of Improvement of Lawyers' ethics regulation and ethical training. Qualitative research was carried out through second part of 2013 and is one part of the mentioned project. The goal of this method was to verify theoretical part of research, i.e. to find out what constitutes contents of legal ethics, to identify and systematize the factors determining compliance with the legal ethics; to identify and reveal the most relevant issues of legal ethics; to reveal chosen aspects of ethical violations and their detection; to identify the most valuable means and tools for prevention of possible ethical violations. A semi-structured, in-depth interview was chosen. Fifteen respondents participated in individual interviews. They were chosen by using target selection, i.e. aiming that sample units reflect the widest range of cases in the area under study. The target group: representatives of five state-regulated legal professions (judges, prosecutors, advocates, bailiffs and notaries) and well-known representatives of Lithuanian society and the media. Legal representatives were chosen aiming that one representative from legal profession has close relations with legal ethics while the second one - without such relation. The results of the project besides other scientific publications are published in collective monograph: GRUODYTE், Edita, BERKMANAS, Tomas, KIRŠIENĖ, Julija, KIRCHNER, Stefan, GERVIENĖ, Silvija, SZYMANSKI, Charles, F., ŽIŽIENĖ, Simona, VERŠINSKAS, Tomas, MALINAUSKAS, Vygantas. Teisininku etika: nuo status quo pavyzdinio modelio link [Legal ethics: from status quo towards exemplary model]. Monograph. Vytautas Magnus University: Vytautas Magnus University Press, 2016. 


\section{Importance of Trust in the Judiciary}

The judiciary system is one of the key pillars of democracy in the country. As such, public trust is a crucial reflection of judicial legitimacy ${ }^{6}$, without which the functioning of the legal system would be harmed ${ }^{7}$. In other words, trust in judiciary is needed for voluntary acceptance of judicial decisions $s^{8}$, especially in cases when judiciary faces a crisis of legitimacy or judicial decisions contradict political majority preferences". "If courts are not publicly supported, non-compliance and non-enforcement might become viable alternatives for the incumbent governments" ${ }^{\prime 10}$. Erosion of trust in the courts weakens one of the pillars of the democracy.

However, in many countries (for example post-Soviet emerging democracies) trust in judiciary is still not fairly emphasized ${ }^{11}$. This is unfortunate since well designed, transparent and scientifically reliable indicators of public trust are crucial for better formulation of adequate policy responses. Often policy decisions are based upon an assumed "public concern" on various matters of justice," in the absence of any reliable scientific measure of confidence"12 and professional evaluation and analysis of statistical data.

"Trust in judiciary" is a complex phenomenon, which can be divided into at least two concepts - trust and confidence ${ }^{13}$. Trust as a social psychological category, is usually employed in context of risk assessment. „The powers entrusted to judges are strictly linked to the values of justice, truth and freedom. The standards of conduct applied to judges are the corollary of these values and a precondition for confidence in the administration of justice" ${ }^{14}$. For example, we usually

6 BÜHLMANN, Mark, KUNZ, Ruth, supra note 2, p. 319.

7 ÇAKIR, Aylin, Aydin, ŞEKERCIOĞLU, Eser. Public Confidence in the Judiciary: The Interaction between Political Awareness and Level of Democracy. Democratization, 2015, vol. 23 , no. 4 , p. 635 .

8 GRIMMELIKHUIJSEN, Stephan, KLIJN, Albert. The effects of judicial transparency on public trust: evidence from a field experiment: effects of judicial transparency on public trust. Public Administration, 2015, vol. 93, no. 4, p. 995.

9 BÜHLMANN, Mark, KUNZ, Ruth, supra note 2, p. 317.

10 ÇAKIR, Aylin, Aydin, ŞEKERCIOĞLU, Eser. supra note 7, p. 635.

11 HOUGH, Mike, SATO, Mai (ed.) Trust in Justice: Why It Is Important for Criminal Policy, and How It Can Be Measured. [online]. Available at: <https://www.heuni.fi/material/ attachments/heuni/reports/6KnfuLmJb/Text_pages_1-47.pdf> Accessed: 05.03.2019.

12 Ibid., p. 15.

13 DOBRYNINAS, Aleksandras, DRAKŠIENĖ, Anna, GAIDYS, Vladas, VILEIKIENĖ, Eglè. Pasitikejimo Lietuvos Teisesauga Profiliai [Profiles of Trust in Lithuanian Law Enforcement]. Vilnius: Vilnius University Press, 2012, pp. 8-11, 138-140, 358.

14 THE CONSUlTATIVE COUNCIL OF EUROPEAN JUDGES. Opinion no. 3 On the principles and rules governing judges' professional conduct, in particular ethics, incompatible behavior and impartiality, par.8. Available at: $<\mathrm{https} / / / \mathrm{rm}$.coe.int/compilation-ofopinions-of-the-consultative-council-of-european-judges/168074fabc\#_Toc493252555> Accessed: 18.11.2018. 
trust people who are responsible, credible, reliable, faithful, because these people keep their word, do not deceive others.

But in terms of court as an institution, the indicator of corruption is one of the most important factors for trust. The factor of corruption is especially sensitive in developing democracies, for example in post-soviet countries. If the person has direct or indirect experience of judge, who was corrupt, "privatized" the public interest while doing justice, such awareness creates a cynical personal attitude to justice. "Impartiality, incorruptibility and trustworthiness of the judiciary" 15 are vital for public trust in courts as institution. So, the rising level of trust in the courts and the judiciary provide some evidence that the public probably sees a reduction in corruption in the courts. However, corruption index surveys show that in opinion of Lithuanian residents, corruption in judiciary is rather high (as is seen from the table below), while in opinion of business sector, corruption is decreasing.

Table 1 Opinion about corruption in judiciary by residents and business leaders ${ }^{16}$

\begin{tabular}{|c|c|c|c|c|}
\hline & $2001(\%)$ & $2004(\%)$ & $2014(\%)$ & $2016(\%)$ \\
\hline Residents & 49 & 36 & 30 & 37 \\
\hline $\begin{array}{c}\text { Business } \\
\text { leaders }\end{array}$ & 52 & 34 & 18 & 18 \\
\hline
\end{tabular}

Still the levels of corruption in judiciary both in opinion of residents and business sector is quite high: in the third place (following Lithuanian Parliament and health care institutions) in opinion of residents ${ }^{17}$ and in the fourth place in opinion by the business leaders (following Lithuanian Parliament, health care and municipal institutions) $)^{18}$.

On the other hand, confidence is also a systemic functional category that emphasizes how both the person and the institution are performing. If courts function well and justice officials are professionals, providing diverse support, it is indicator of well-established justice system. "Court efficiency plays a crucial role for upholding the rule of law, by ensuring that all persons, institutions and entities, both public and private, including the State, are accountable, and by guar-

15 ÇAKIR, Aylin, Aydin, ŞEKERCIOĞLU, Eser. supra note 7, p. 635.

16 Data about 2014 and 2016 are taken from: Lietuvos korupcijos žemélapis. Gyventoju ir verslo atstovu korupcijos vertinimu ir patirties tyrimai [the Lithuanian map of corruption. Investigations of Corruption Assessments and Experiences of Population and Business Representatives]. [online]. Available at: <https://www.stt.lt/documents/soc_tyrimai/ KZ_2004.pdf> Accessed: 21.02. 2019. VILMORUS. Lietuvos korupcijos žemelapis. [the Lithuanian map of corruption] [online]. Available at: <https://www.stt.lt/lt/menu/tyrimaiir-analizes/?print=1> Accessed: 21.02.2019.

17 VILMORUS. Lietuvos korupcijos žemelapis. [the Lithuanian map of corruption], p. 88 [online]. Available at: $<$ https://www.stt.lt/lt/menu/tyrimai-ir-analizes/?print=1 $>$ Accessed: 21.02.2019.

18 Ibid, art. 90. 
anteeing timely, just and fair remedies" ${ }^{\prime 19}$. Professional, legitimate, fair, respectful behavior is not only desirable, but is a prerequisite for effective performance, which creates public confidence.

According to various public surveys, the trust in the judiciary in Lithuania has steadily increased in the last several years. Survey conducted by public opinion research company Baltijos tyrimai in 2018, showed that almost half (49\%) of respondents expressed confidence in the judiciary. This is the highest score of trust in since January 1996 when the trust of institutions has started being analyzed monthly. The findings of various public surveys of public trust in judiciary in Lithuania in period from 2013 to 2018 are depicted in graph No. 1. According to public opinion research company Baltijos tyrimai, over the past 22 years, the respective rate of distrust has always been higher than rate of confidence. Only in June of 2017 a positive rate of trust in courts was recorded. The lowest score of trust was indicated in May of 2010, when even 74 percent of respondents expressed their distrust in judiciary in Lithuania (while only $17 \%$ expressed trust) $)^{20}$.

\section{Graph No. 1 Trust in Judiciary in Lithuania ( \%)}

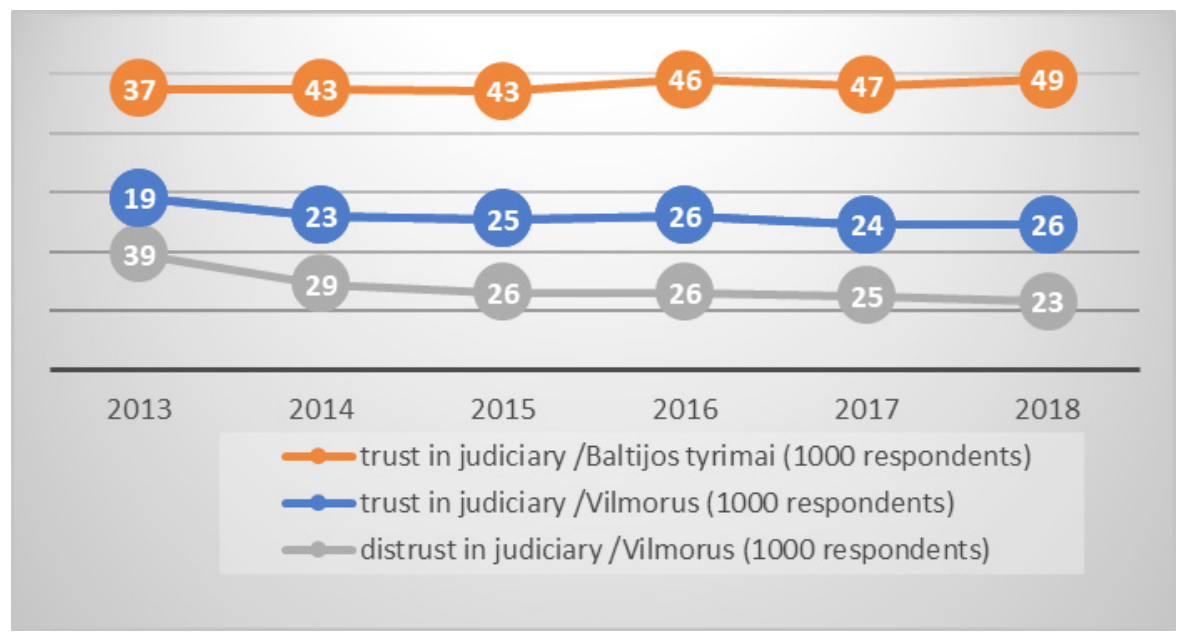

This growing public confidence rates in the judiciary is a positive development. As our analysis indicates, it appears to reflect the efforts that have been

19 THE EUROPEAN COMMISSION FOR THE EFFICIENCY OF JUSTICE. European judicial system. Efficiency and quality of justice, p. 47. [online]. Available at: <https://rm.coe. int/european-judicial-systems-efficiency-and-quality-of-justice-cepej-stud/1680788228> Accessed: 07.05.2019.

20 BRUNALAS, Benas. Naujausios Apklausos: Rekordinis Pasitikejimas Teismais [Latest Surveys: Record Trust in Courts]. [online]. Available at: <https://www.delfi.lt/a/78638041> Accessed: 23.08.2018. 
invested into respective policy measures (communication, the aid measures for witnesses and victims, new technologies). The judiciary, however, still have comparatively low trust scores in institutions in Lithuania. But it nonetheless ranks ahead of other public institutions - political parties, parliament and government in the level of public trust ${ }^{21}$. In contrast, fire and rescue service, police, army, president and church deserve the highest public trust scores ${ }^{22}$.

It should be noted, that in the public opinion surveys about $50 \%$ of respondents generally answer that they do not know or do not have an opinion on the subject and only about 8 percent of population had any direct experience with the courts ${ }^{23}$. So, it can be interfered that the attitude of remaining $92 \%$ was shaped by other sources, one of which is the media. News portals and social networks contain ample of material about rankings and these publications affect people's perceptions, too.

Arguably it is hard to create public confidence, but easy to lose it. It is interesting to note, that just before submission of this paper to the journal, the public trust in judiciary in Lithuania was very seriously shattered by scandal of corruption of judges. Moreover, it was the biggest judiciary corruption scandal in Lithuania ever involving about thirty people, including eight top judges, attorneys and other lawyers. The detained judges served at higher level courts including the Supreme court, the appeal court and other courts. Also, five attorneys were among the detained. As the prosecutor said: "It was a system ... what we found was that, in an attorney's office, trading in justice was taking place"24. Anti-corruption agency head Zydrunas Bartkus said the agency had evidence of bribes, ranging from 1,000 euros to 100,000 euros, given to influence verdicts in a range of administrative, civil and criminal court cases ${ }^{25}$.

As this case is still ongoing and final verdicts are not yet taken, we can only observe now how this scandal influenced public trust in judiciary. Not surprisingly the levels of public trust felt almost twice and returned even to the lower level than five years ago. As it was commented by sociologist after the scandal, „Typically, public trust is very suddenly knocked down by negative events, how-

21 VILMORUS, 2018. Available at: <http://www.vilmorus.lt/index.php?mact=News,cntnt01, detail,0\&cntnt01articleid=2\&cntnt01 returnid=20> Accessed: 23.11. 2018.

22 Naujausia apklausa: šalies gyventojai labiausiai pasitiki ugniagesiais gelbetojais [The latest survey: The country's residents rely most on firefighters] [online]. Available at: <http:// kauno.diena.lt/naujienos/lietuva/salies-pulsas/naujausia-apklausa-salies-gyventojai-labiausiai-pasitiki-ugniagesiais-gelbetojais-877165> Accessed: 01.03.2019.

23 VAIČELIŪNAITĖ, Gabija. A. Dobryninas: Apie Pasitikèjima Teismais Ir Požiūrị ị Valstybę [A.Dobryninas. About Trust in Justice and Attitude to the State]. [online]. DELFI. Available at: <https://www.delfilt/a/76660913> Accessed 23.08.2018.

24 REUTERS. Lithuania Arrests Eight Top Judges in Anti-Corruption Crackdown. [online]. Available at: <https://www.reuters.com/article/us-lithuania-corruption-idUSKCN1Q922O > Accessed 20.06.2019.

25 Ibid. 
ever it takes a long time for trust to recover"26. On the other hand, these facts only reaffirm the arguments regarding building and sustaining public trust elaborated in this paper.

The opinion about the institution depends not only on our personal experience but also on other important sources like: friends, family members, colleagues, media ${ }^{27}$. So, transparency about judicial decision-making procedures and performance helps building trust, even though negative experience has a much more pronounced effect on citizen attitudes than good one ${ }^{28}$. High levels of knowledge about the work of judiciary usually have a positive effect on public trust scores ${ }^{29}$. Even the publications in mass media about public trust rates can affect society's attitudes, because people process information in correlation with certain beliefs or knowledge they already have, i.e. information is interpreted in terms of their pre-existing knowledge ${ }^{30}$. Therefore, it is crucial clearly highlight judicial professionalism and provide performance-based explanations.

In this regard, attractiveness of the institution to the public (scores of public opinion) shall not be identified with the efficiency of performance ${ }^{31}$, as these aspects not always coincide. For example, a court decision may not suit me, but it is just. Justice is a complex matter; its perception requires a certain level of knowledge $^{32}$ and should not be measured by number of likes. So, transparency about judicial decision-making procedures and performance helps building trust $^{33}$. Traditionally, judicial transparency has been attained by the openness of cases, i.e. everyone could attend court hearings ${ }^{34}$.

The rapidly changing communication technologies ${ }^{35}$ encourage court systems to look for ways to clearly highlight judicial professionalism and perfor-

26 GAIDYS, Vladas. Sociologas: atsistatyti gyventoju pasitikejimui teismais užtruks, [Sociologist: It will take time to restore the confidence of the people in the courts]. [online]. Available at: <https://www.15min.lt/naujiena/aktualu/lietuva/sociologas-atsistatyti-gyventojupasitikejimui-teismais-uztruks-56-1133674> Accessed 08.07.2019.

27 ÇAKIR, Aylin, Aydin, ŞEKERCIOĞLU, Eser. supra note 7, p. 636.

28 BAUMEISTER, Roy, F, BRATSLAVSKY, Ellen, FINKENAUER, Catrin, VOHS, Kathleen, D. Bad Is Stronger than Good. Review of General Psychology, 2001, vol. 5, no. 4, pp. 323.

29 GRIMMELIKHUIJSEN, Stephan, KLIJN, Albert, supra note 8, p. 995.

30 Ibid., p. 998.

31 CURTIN, Deirdre, MEIJER, Albert, Jacob. Does Transparency Strengthen Legitimacy? Information Polity, 2006, vol. 11, no. 2, p. 109.

32 TYLER, Tom, R. Public Trust and Confidence in Legal Authorities: What Do Majority and Minority Group Members Want from the Law and Legal Institutions? Behavioral Sciences \& the Law, 2001, vol. 19, no. 2, pp. 216-217.

33 Ibid., pp. 233-234.

34 GRIMMELIKHUIJSEN, Stephan, KLIJN, Albert, supra note 8, p. 997.

35 „citizens are generally satisfied with the electronic provision of information (transparency) $<\ldots>$ and electronic government strategies-transaction, transparency, and interactivity-are important factors that directly affect satisfaction and indirectly affect trust, . WELCH, Eric, W., HINNANT, Charles, C., MOON, Jae, M. Linking Citizen Satisfaction 
mance-based explanations for effective justice. Visual information is becoming more important and cultural theorists even argue that we live in a 'visual culture $^{36}$. The unique traits of visual judicial transparency expose myth of legality and its typical judicial symbols that imply impartiality: a courtroom, a gavel, a gown. In recent years, Lithuanian court administration took measures of active communication in order the judicial system would become more visible, seeking to create the atmosphere of trust and openness, presenting judges as persons, the members of the same society. Opinion leaders and power holders may play a central role in shaping public awareness about the judicial system. For example, Lithuanian president Dalia Grybauskaite, which is among the most trusted politicians in Lithuania ${ }^{37}$. During her presidency she demonstrated high intolerance to any disruptions or unprofessional behavior of judiciary. This also presumably committed to growing public trust in courts in Lithuania.

Judiciary is just one of the state powers, and studies show that trust in courts correlates with the trust of other state institutions. So, it is also a matter of general political trust. The level of democracy and scores of public trust of the state and other public institutions have a significant impact on the trust scores of judiciary. In Lithuania, the scores of public confidence in the Parliament (Seimas) and government are one of the lowest. The post - soviet legacy is often blamed ${ }^{38}$. On the other hand, research of the phenomenon of corruption in society, show that there is a strong connection between the public trust in state institutions and the assessment of their corruption ${ }^{39}$.

\section{Rise in public trust of judiciary: reasons}

\subsection{Efficiency and quality}

Several important developments provide insights into the rising confidence in the Lithuanian judiciary and courts. We explore first efficiency and quality, which are criteria used by the European Commission ${ }^{40}$ to evaluate judicial systems. Efficiency and quality are also indicators suggested by the Council of European Commission ${ }^{41}$. EC measures courts' efficiency through caseload, time

with E-Government and Trust in Government, Journal of Public Administration Research \& Theory, 2005, vol. 15, no. 3, p. 371.

36 Ibid., GRIMMELIKHUIJSEN, Stephan, KLIJN, Albert, supra note 8, p. 997.

37 VILMORUS, 2019. Available at: <http://www.vilmorus.lt/index.php? $m a c t=N e w s, c n t n t 01$, detail,0\&cntnt01articleid=4\&cntnt01 returnid=20> Accessed: 23.02. 2019.

38 KIRŠIENÉ, Julija. Trimate teisininko profesijos krizès problema [The crisis of legal profession as three-dimensional problem]. Jurisprudencija, 2015, vol. 22, no. 2, pp. 196-198.

39 ÇAKIR, Aylin, Aydin, ŞEKERCIOĞLU, Eser. supra note 7, p. 638.

40 THE EUROPEAN COMMISSION. The 2018 EU justice scoreboard, Communication from the Commission to the European Parliament, the Council, the European Central Bank, the European Economic and Social Committee and the Committee of the Regions. Available at: // <https:// ec.europa.eu/info/sites/info/files/justice_scoreboard_2018_en.pdf> Accessed: 10.10.2018.

41 THE EUROPEAN COMMISSION FOR THE EFFICIENCY OF JUSTICE, supra note 19, pp. 46-47. 
needed to resolve cases, number of pending cases in court, while quality is measured by such criteria as accessibility (including availability of online information about judicial system for inhabitants), resources, assessment rates and standards in place ${ }^{42}$. We recognize that these criteria could be taken as (pre)defined quality parameters or fixed standards of quality, efficiency and professionalism of judiciary. Quality "is a broad concept and many options are possible as regards its measurement, on the basis of the needs and objectives of the evaluation" ${ }^{4}$. In other words, we recognize that there is no dispositive list of concrete criteria. These variables serve, however, as the best available proxies to assessing the general level of the court system in the EU countries. Administrative effectiveness, time and cost ratio, and usage of technologies, allows comparison with the analogous systems in other Member States. Measuring these variables does not indicate directly the level of trust or satisfaction of society with existing justice system or real quality of court decisions. Nonetheless, it provides important and helpful insights.

In terms of criteria, used to measure courts' efficiency and quality by European Commission (such as caseload, time needed to resolve cases, number of pending cases in court, availability of online information resources, assessment rates, etc.) Lithuania is positioned in rather good position on the most of these quantitative criteria. For example, for the time needed to resolve cases Lithuania courts are in the third place after Denmark and Estonia ${ }^{44}$, while for the time needed to resolve: civil and commercial cases in the second place ${ }^{45}$, administrative cases - in the first place ${ }^{46}$. Lithuania is in the third place (after Sweden and Belgium) regarding the number of pending cases and the amount of these cases is lower than in 2014-2015 ${ }^{47}$. Lithuania is in the highest position regarding standards on information about case progress ${ }^{48}$. These scores show an excellent trend in terms of good performance, especially given that the general Lithuanian state budget total expenditure on courts (in Euros per inhabitant) is one of the lowest in EU - a bit less is spent only in Romania and Cyprus ${ }^{49}$.

Development of technology tools (hereinafter-IT) is treated by the Comission of the European Council as one of the tools to improve efficiency of judicial system $^{50}$ and could help small countries such as Estionia or Lithuania to con-

42 THE EUROPEAN COMMISSION, supra note 40, pp. 9-10.

43 Ibid., p. 5.

44 Ibid., p. 11

45 Ibid.

46 Ibid., p. 12.

47 Ibid., p. 15.

48 Ibid., p. 38.

49 Ibid., p. 30.

50 THE EUROPEAN COMMISSION FOR THE EFFICIENCY OF JUSTICE. Guidelines on how to drive change towards cyberjustice. Stock-taking of tools deployed and summary of good practices. [online]. Available at: <https://edoc.coe.int/en/efficiency-of-justice/7501guidelines-on-how-to-drive-change-towards-cyberjustice-stock-taking-of-toolsdeployed-and-summary-of-good-practices.html> Accessed 10.07.2018. 
tribute to the development of the EU itself. ${ }^{51}$ Looking into various criteria provided by the CEPEJ, Lithuania courts are in high position on certain criteria. For example, Lithuania is one of three countries where all six categories of information are available online ${ }^{52}$; one of four EU countries where electronic tools are used to submit a case, to monitor proceedings and to transmit summons are in place $^{53}$; and one out of seven EU countries where small claims procedures are fully online ${ }^{54}$.

No direct connection between IT and trust in society can be established but indirect link can be seen. "Network technology can support increasing public trust by providing an effective means of communication between courts and their users and the general public" ${ }^{35}$. IT is an important indicator evaluating efficiency, quality and trust in implementation of justice ${ }^{56}$. Empirical research confirm IT importance for implementation of judiciary functions as seen from graphs No. 2 and No. 3. Together these logically support a reason for growing trust in the implementation of justice.

\section{Graph No. 2 Importance of IT for implementation of work functions in Lithuanian judiciary}

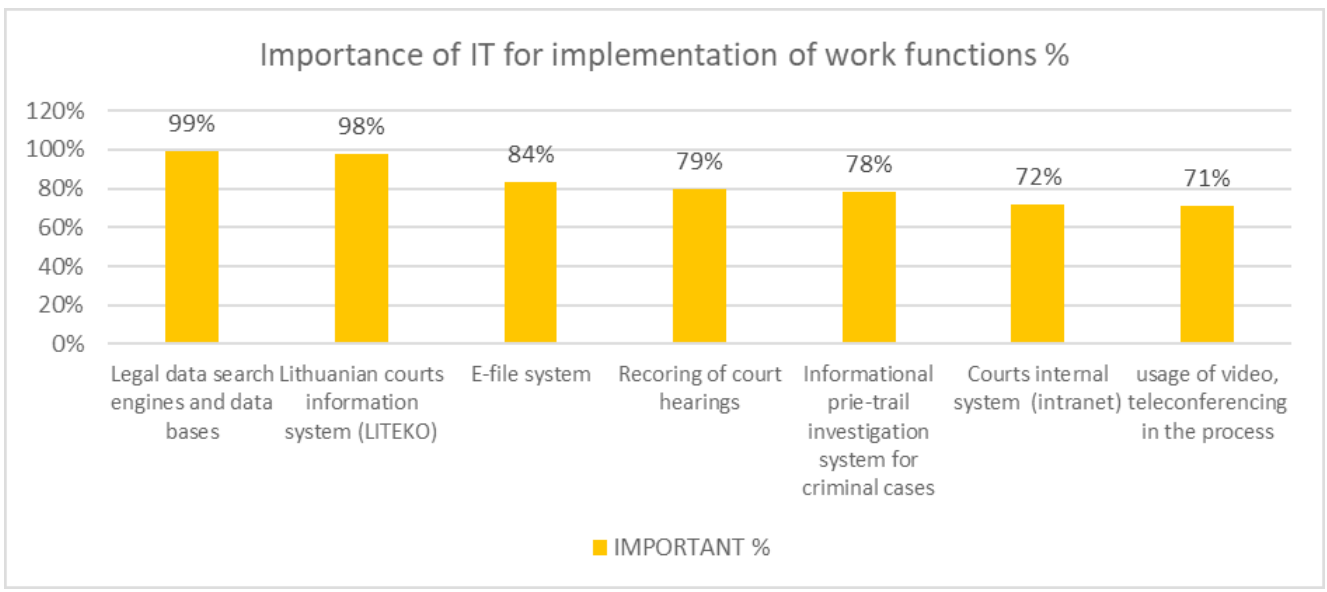

51 FISCHER, Dirk-Hinnerk. Making a Mark-Time Changing Politics from Estonia: An Alternative Idea for the British, Bulgarian and Estonian EU Presidency. Baltic Journal of European Studies, 2016, Vol. 6, No. 1, pp. 185.

52 THE EUROPEAN COMMISSION, supra note 40, p. 23.

53 Ibid., p. 25.

54 Ibid., p. 26.

55 REILING, Dory. Technology for justice. How information technology can support judicial reform. Dissertation. Leiden: Leiden university press, 2009, p. 254.

56 EGONDA-NTENDE, Frederick. The Role of Information Technology in Modernising the Courts. [online]. Presented to a Conference of the Southern African Judges Commission, Uganda, 3-6 February 2005. Available at: <http://www.venice.coe.int/SACJF/2005_02_ UGA_Entebbe/Rep_Egonda_Ntende.htm > Accessed: 08.07.2018. 
ICLR, 2019, Vol. 19, No. 1.

\title{
Graph No. 3 Advantages of IT in Lithuanian courts
}

\section{Advantages of IT in courts \%}

\author{
IT increased sense of community
}

IT accelerates the adoption of decisions

IT provided the opportunity to organize part of the work. IT helps to pay more attention to the analysis of legal problems

IT saves time that can be devoted to more complex and...

IT contributes to the implementation of justice

IT makes judicial system more attractive to the public

IT helps protect natural resources

IT improved working conditions

IT enables more efficient access to information from state..

IT improved sharing of best practice

IT makes judicial system more advanced

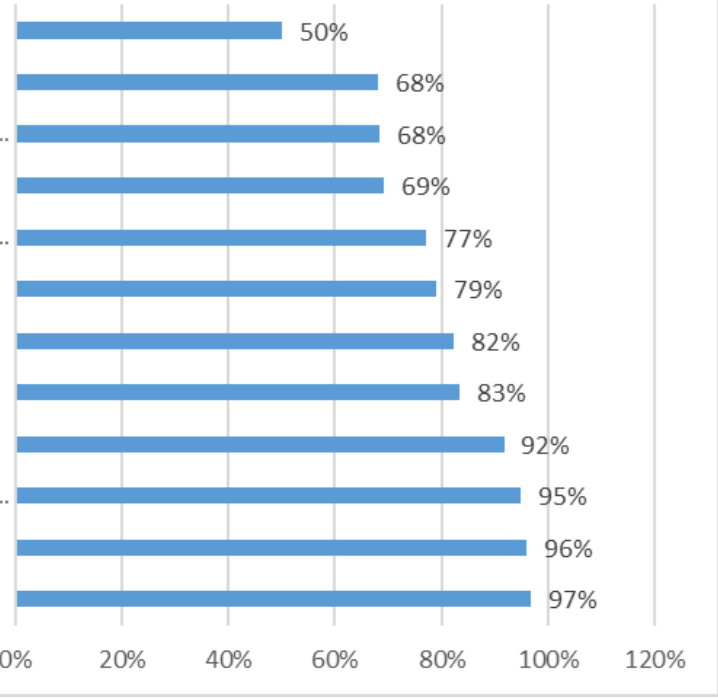

However, IT in justice system "must be also considered as a risk factor" if poorly implemented which is either indicated by respondents (graph No. 4 and No. 5).

\section{Graph No. 4 Disadvantages of IT in Lithuanian courts}

Disadvantages of IT in courts \%

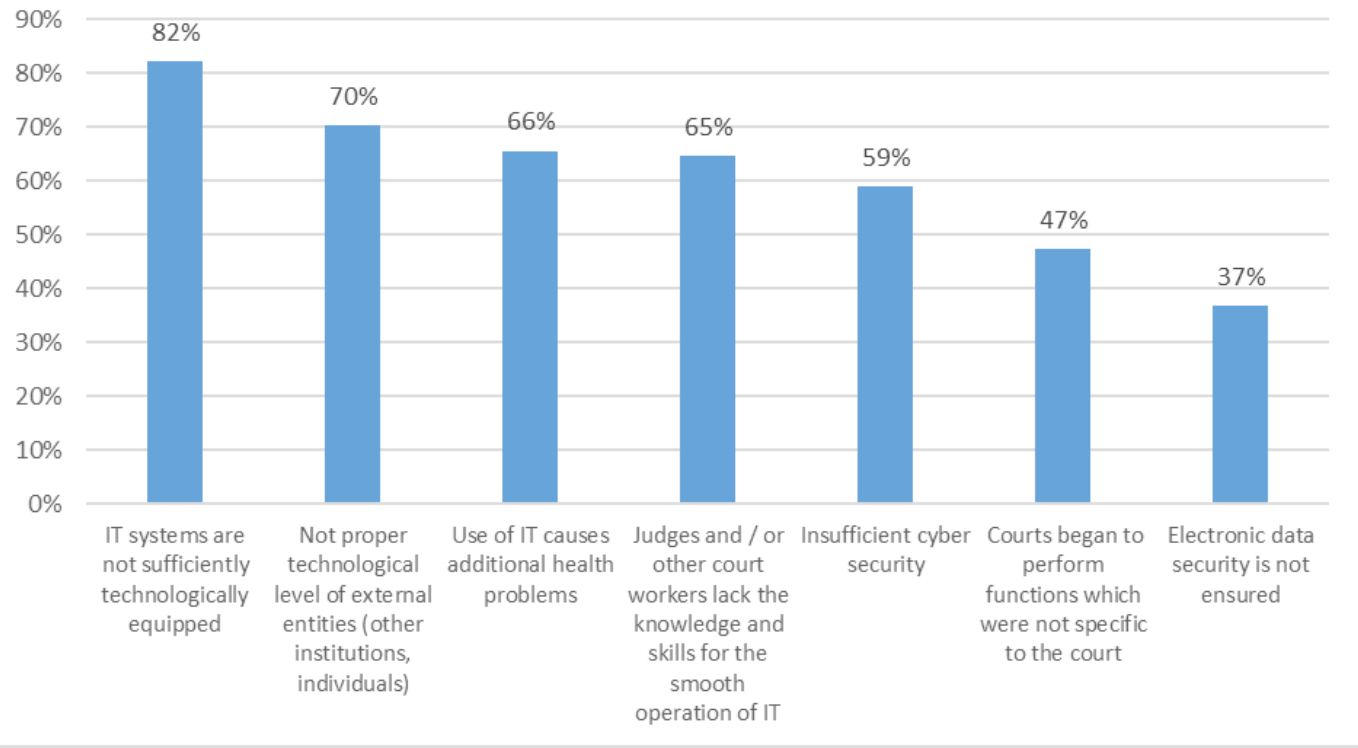

Published by Palacký University Olomouc, Czech Republic, 2019.

ISSN (print): 1213-8770; ISSN (online): 2464-6601 


\section{Graph No. 5 Lacking aspects for well-being at work in Lithuanian courts}

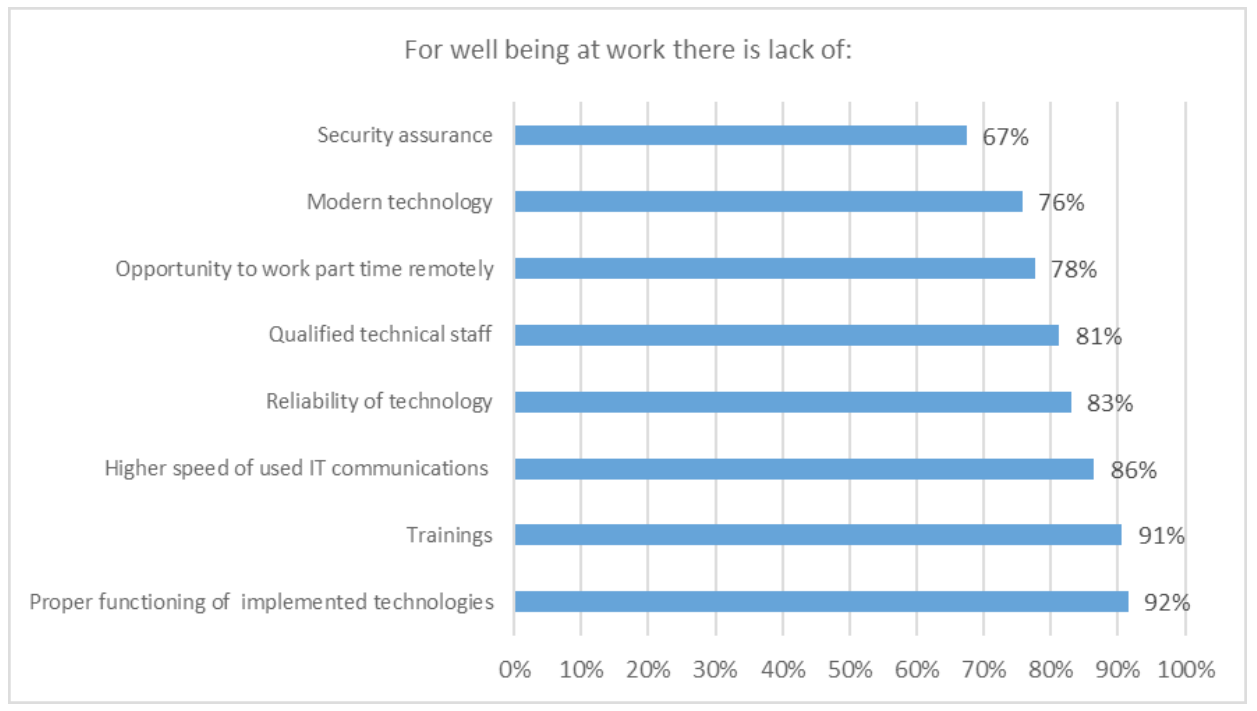

Technologies have large impact on user's mental and physical health and could be one of the stress factors in the workplace ${ }^{57}$ and probably could have negative effect on efficiency and quality aspects of judiciary which is indicated in graph No. 6.

\section{Graph No. 6 Emotional aspects of IT in Lithuanian courts}

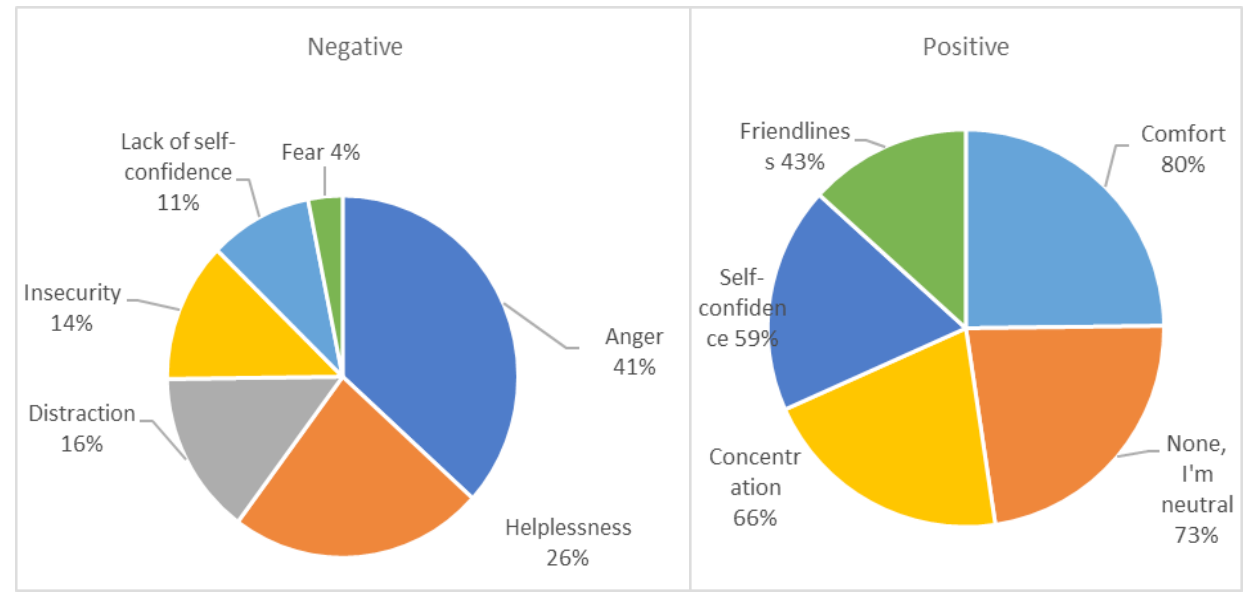

57 RAIŠIENĖ, Agota, Giedrè, JONUŠAUSKAS, Steponas. Informacinių ir komunikacinių technologiju ittaka darbuotojų technostresui: situacijos Lietuvoje charakteristika [Influence of information and communication technologies on employee technostress: situation in Lithuanian organizations]. INFORMACIJOS MOKSLAI, 2013, vol. 66, pp. 91-92. 
The most negative direct impact of IT as seen by respondents - mistakes in procedural documents and missed deadlines, but it is not clear if this correlates with efficiency and professionalism.

\section{Graph No.7 Actual negative IT aspects in Lithuanian courts}

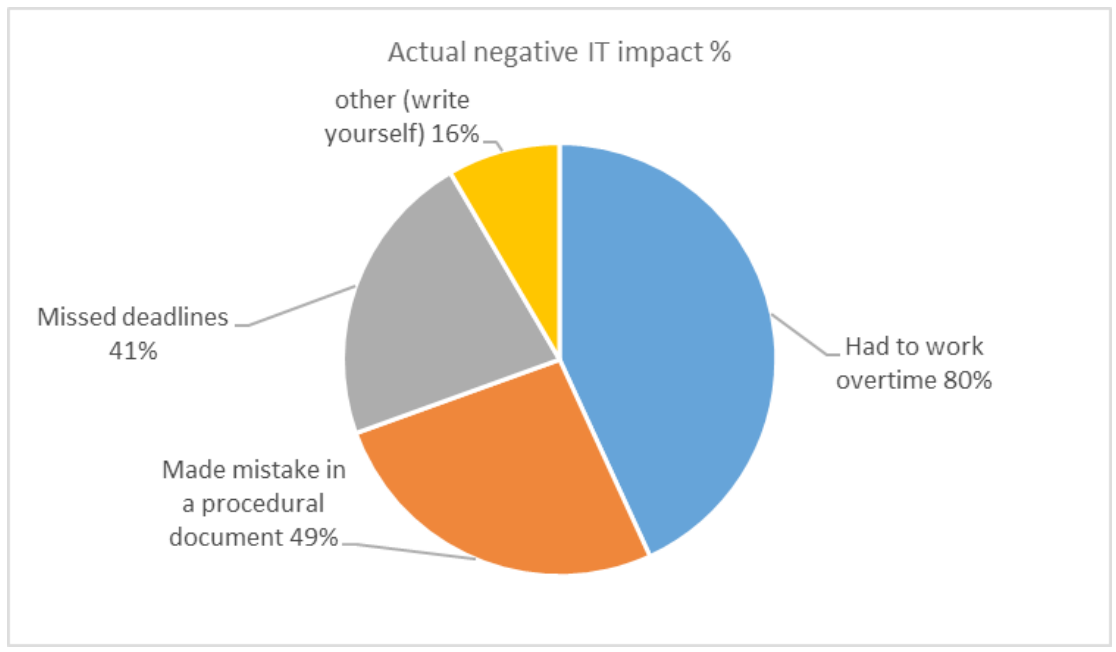

\subsection{Standards for Professionalism that Creates Confidence}

In addition to efficiency, quality and a reduction in corruption, the professionalism of the actors who function in the courts is also important. Professional requirements for regulated legal professions including judiciary are established in international documents ${ }^{58}$, the doctrine of constitutional $\operatorname{court}^{59}$ and national regulation. It is self-evident that highest professional standards require the highest standards

58 Example in Committee of Ministers (Council of Europe) Recommendation Nr.(94)12, it is provided that "In the decision-making process, judges should be independent and be able to act without any restriction, improper influence, inducements, pressures, threats or interferences, direct or indirect, from any quarter or for any reason. The law should provide for sanctions against persons seeking to influence judges in any such manner. Judges should have unfettered freedom to decide cases impartially, in accordance with their conscience and their interpretation of the facts, and in pursuance of the prevailing rules of the law. Judges should not be obliged to report on the merits of their cases to anyone outside the judiciary. Section I (d) (Adopted by the Committee of Ministers on 13 October 1994 at the 518th meeting of the Ministers' Deputies). Available at: <https://www.barobirlik.org.tr/dosyalar/duyurular/hsykkanunteklifi/recR(94)12e.pdf> Accessed: 02.07.2018; The Universal Charter of the Judge; European Charter on the statute for judges; Basic Principles on the Independence of the Judiciary (UN); The Bangalore Principles of Judicial Conduct and etc.

59 Example, Ruling of the Constitutional Court on 10th of July 1996 (Official Gazette, 1996, No. 67-1628); Ruling of the Constitutional Court on 20th of February 2008 (Official Gazette, 2008, No. 23-852; 201). 
of ethics as status of judges implies special status in society ${ }^{60}$ and obligation to act not only in accordance with the rule of law but also being epitome of morality and decency. In accordance with UN Basic Principles "On the Independence of the Judiciary" judges shall always conduct "themselves in such a manner as to preserve the dignity of their office and the impartiality and independence of the judiciary ${ }^{\prime \prime 61}$, which stresses importance of the behavior of judge both implementing professional duties and during remaining time. Requirements of the highest ethical standards are derived from the importance of their role in society $:<\ldots>$ in a state under the rule of law the highest possible professional qualification requirements as well as those of legal education can and must be raised to the persons who seek to become judges"62.

The need for accountability of judges to the public is emphasized in the recommendations of the European Judicial Council: "the corollary of the powers and the trust conferred by society upon judges is that there should be some means of holding judges responsible, and even removing them from office, in cases of misbehavior so gross as to justify such a course"63. Hereinafter it is discussed how these principles and recommendations are reflected in Lithuania regulation and practice.

Comparative analysis of disciplinary systems for European judges and prosecutors indicate that one of the purposes of disciplinary systems is the trust of the citi$z^{2} s^{64}$. Main purpose of disciplinary system in Lithuania resembles the issues found in Europe as two main interrelated objectives are provided:

- The priority of common human values ("to fix that justice and other universal human values in the activities of the courts takes priority");

- Increasing the authority of judges in the eyes of the public ("to enhance the trust of public in the courts and judges, to increase their authority") ${ }^{65}$.

Ethics is one of criteria of impeccable reputation ${ }^{66}$. A disciplinary violation could be established for three interrelated categories of misbehavior: 1. demeaniation of

60 RUZGYTĖ, Eglè. Teisininko profesija ir etika: riba tarp teisès ir moralès [The legal profession and ethics: the line Between law and morality]. Parlamento studijos, 2017, vol. 23 , p. 123.

61 UN. Basic Principles on the Independence of the Judiciary, sec.8 [online]. Available at: $<$ https://www.ohchr.org/en/professionalinterest/pages/independencejudiciary.aspx $>$ Accessed: 02.07.2018.

62 RULING OF THE CONSTITUTIONAL COURT. Official Gazette, 2008, No. 23-852, par.3, sec.6.

63 THE CONSULTATIVE COUNCIL OF EUROPEAN JUDGES, supra note 13, par. 51.

64 NAIS, Acquaviva, FLORENCE, Castagnet, MORGANE, Evanghelou. A comparative analysis of disciplinary systems for European judges and prosecutors, p. 2. [online]. Available at: $<$ http://www.ejtn.eu/Documents/Themis\%202012/THEMIS\%202012\%20ERFURT\%20 DOCUMENT/Written\%20paper\%20France\%203.pdf> Accessed: 16.02.2019.

65 Code of ethics of the judges of the Republic of Lithuania Adopted by a General meeting of the Lithuanian judges on June 28, 2006, No. 12P-8, art.2. Available at: <http://www.teismai. lt/en/self-governance-of-courts/judicial-court-of-honour/about-court/664 $>$ Accessed: 18.02.2019.

66 Lietuvos Respublikos teismų istatymas, [The Law on the Courts of the Republic of Lithuania], art.52. Official gazette, 2002, No. 17-649. 
the judicial office; 2. violation of other requirements of the Code of Ethics of Judges; 3.non-compliance with the limitations on the work and political activities of judges provided by law ${ }^{67}$. Disciplinary cases are decided by the Judicial Court of Honor (JCH), in which from July $2014^{68}$ four members out of ten are delegated by the Chair of Parliament and by the president of the State (analogous institutions of attorneys, notaries and bailiffs are still formed only by the representatives of profession). Up till September 2008 the right to make a motion for instituting a disciplinary action had only limited number of persons (the Judicial Council, the Judicial Ethics and Discipline Commission and the Chairperson of the court where a judge is employed or the Chairperson of any court of a higher level) while after changed regulation - any person ${ }^{69}$. As additional advantage of judiciary ethics - transparency and openness of the system as all decisions of the JCH are not anonymous and published on the open web page ${ }^{70}$. It is important that big efforts are provided for prevention of possible infringements of legal ethics by the initiative of the Judicial Ethics and Discipline Commission (judicial self-governance institution deciding the issues of instituting disciplinary actions against judges) ${ }^{71}$ which provide individual anonymous consultations on the issues of legal ethics which are published on the web and available to any interested person. From 2013 by initiative of this commission the practical guide for judges on the issues of legal ethics (which they are updating) is created and openly available on the web. Any interested person could find explanations of certain norms of the Judicial code of ethics, provided in cases both by the JCH or the Supreme Court (appeal institution for reviewing of decisions of $\mathrm{JCH})^{72}$.The smallest number of disciplinary cases in Lithuania is initiated for judges. Example during 2002-2012 in average $0,8 \%$ (5,8 cases) per year, accordingly in 2016 only two cases, while in 2016 four disciplinary cases were started ${ }^{73}$.

Judicial training is financed by the state and should provide at least $1.5 \%$ of the judges' salary ${ }^{74}$. In accordance with legal regulation compulsory judicial training should be provided at least every five years if other special conditions (example, the legal regulation of public relations is fundamental changes in society regulation) are

67 Ibid., art.83.

68 Ibid., art.122.

69 Ibid., art. 84.

70 Teiseju etikos ir drausmes komisijos konsultacijos [Consultations of the Judicial and Ethics Commission]. [online]. Available at: $<$ https://www.teismai.lt/lt/teismu-savivalda/teisejuetikos-ir-drausmes-komisija/konsultacijos/185/2018-05> Accessed: 24.06.2018.

71 The Law on the Courts, supra note 66, art. 85.

72 NORKŪNAS, Algis, GUTAUSKAS, Aurelijus,VALYTĖ, Toma, PAULIUKAITĖ, Aurelija. (2017) Lietuvos Respublikos teiseju etikos kodeksas - praktinis vadovas [Code of ethics of the judges of the Republic of Lithuania - Practical guide] [online]. Available at: <https:// www.teismai.lt/data/public/uploads/2017/09/tek-praktinis-vadovas-2017-09-29.pdf> Accessed: 21.02. 2019.

73 Teismu veiklos apžvalga [Review of judicial activity]. [online], p. 46. Available at: <https:// www.teismai.lt/data/public/uploads/2018/04/d1_galutine-ataskaita-10.pdf > Accessed: 24.02.2019.

74 The Law on the Courts, supra note 66, art. 94. 
not established ${ }^{75}$. Judicial training programs, in agreement with the Ministry of Justice, are approved by the Judicial Council ${ }^{76}$. Changing attitude to the professionalism is Lithuania is reflected by increased role of judicial training. For example in 201785 $\%$ of judges raised their qualification in national training programs approved by the Judicial Council (accordingly in $2016-84 \%$ and in $2015-73 \%)^{77}$. This increased number of participants was due to the increased number of approved training programs and the number of trainings organized as a result of increased funding which means that in the next years it could deteriorate if finances are not obtained. Even though overview of existing disciplinary system for infringements of legal ethics and prevention indicates that important steps are taken for transparency and intolerance of unethical behavior still there is place for improvements as "infringements of legal ethics is very delicate and latent problem; most of these violations do not even reach the courts of honor, because usually such judges resign without waiting the verdict for possible violation avoiding any negative consequences and often continue their careers in other legal positions"78.

It is impossible to draw unambiguous conclusion that actual situation with disciplinary liability helped to increase trust by society, but evaluating efforts of selfdisciplinary bodies, aiming for non-tolerance of improper behavior and principled actions in case infringement is found it could be expected.

\subsection{Country's level of democracy}

Trust in judiciary, efficient enforcement of rule of law, impartial and non-political decision making, and transparency increase public trust in judiciary ${ }^{79}$. These also are the features of well-functioning democracies, notwithstanding the fact that recent developments in certain Members States indicate that core EU values, such as respect for rule of law, the principle of democracy and human rights are jeopardized. ${ }^{80}$ According to Democracy index of $2017^{81}$, Lithuania was ranked 37 among 167 countries (Norway is ranked as first and North Korea - the last). According to

75 Ibid., art.92.

76 Ibid., art.93.

77 Review of judicial activity, supra note 73, p. 63.

78 KIRŠIENĖ, Julija, supra note 38, pp. 198-199.

79 BÜHLMANN, Mark, KUNZ, Ruth, supra note 2, p. 318; GIBSON, James, L. CALDEIRA, Gregory, A. Citizens, courts, and confirmations: Positivity theory and the judgments of the American people. Princeton: Princeton University Press, 2009, pp. 1-4.

80 SCHROEDER, Werner. The EU Founding Values - Constitutional Character and Legal Implications. EUROPEAN STUDIES, 2016, vol. 3, pp. 50-64.

81 The Economist Intelligence Unit. Democracy Index, Free speech under attack. [online], pp. 5-9. Available at: <https://pages.eiu.com/rs/753-RIQ-438/images/Democracy_ Index_2017.pdf> Accessed: 18072018 
report of World Economic Forum of 2017/2018, judicial independence ${ }^{82}$ in Lithuania is ranked 56 among 137 countries $^{83}$.

Research show that relationship between high awareness level (political savvy) ${ }^{84}$ and confidence in the judiciary are more evident in advanced democracies ${ }^{85}$. In countries with poor democratic performance, the result of high levels of knowledge about judiciary has "a cynical public effect on individual level" ${ }^{\text {", }}$, because more informed people seem to notice the failures and chronic systemic problems of justice system.

Interestingly, general public confidence in advanced democracies sometimes tend to be lower than in hybrid and authoritarian regimes ${ }^{87}$, so transparency and public awareness in developing democracies could have negative impact on public confidence in the judiciary. In other words, healthy amount of mistrust among the critical citizens is the sign of democracy ${ }^{88}$. Therefore, the effects of transparency are heavily debated in the literature ${ }^{89}$. Respectfully, level of confidence in the judiciary can be also indicator of democratic performance of a country, so it shall be analyzed in relation of level of democracy.

\section{Conclusions}

The rise of public trust rates in Lithuania is not a coincidence. It is the result of invested policy measures, especially in efficiency, quality and public communication. The main reasons that effect the public trust in judiciary (good performance, public communication, country's level of democracy) are strictly interdependent. EU measures courts' efficiency and quality through caseload, time needed to resolve cases, number of pending cases in court, accessibility, resources, assessment rates, etc., but these criteria should not be taken as the (pre)defined quality parameters or fixed standards of quality, efficiency and professionalism of judiciary. Good performance is a braod concept and there is not, nor could be the final list of indicators to measure it. In EU Justice scoreboard, scores reflecting quality and efficiency, as well as tools of cyber justice of Lithuanian courts show an excellent trend in terms of good per-

82 "independence of the judiciary fosters political confidence: the more independent of external political and societal forces a judicial system in a given country is, the greater the probability that an individual living in that country has confidence in the judicial system." Bühlmann and Kunz, supra note 2, p. 334.

83 SCHWAB, Klaus. (Ed) The Global Competitiveness Report 2016-2017: insightreport. [online], p. 185. Available at: <http://www3.weforum.org/docs/GCR2016-2017/05FullReport/TheGlobalCompetitivenessReport2016-2017_FINAL.pdf> Accessed: 24.11.2018.

84 Knowledge about the political system and its institutions, interest and participation in political processes are key individual traits for political savvy.

85 GRIMMELIKHUIJSEN, Stephan, KLIJN, Albert, supra note 8, p. 997.

86 ÇAKIR, Aylin, Aydin, ŞEKERCIOĞLU, Eser. supra note 7, p. 636.

87 Ibid., p. 650.

88 BÜHLMANN, Mark, KUNZ, Ruth, supra note 2, p. 318.

89 LICHT, Jenny de Fine. Do We Really Want to Know? The Potentially Negative Effect of Transparency in Decision Making on Perceived Legitimacy. Scandinavian Political Studies, 2011, vol. 34, no. 3, pp. 183-201; CURTIN, Deirdre, MEIJER, Albert, Jacob. Does Transparency Strengthen Legitimacy? Information Polity, 2006, vol. 11, no. 2, pp. 109-122. 
formance, especially in the context of the fact, that general Lithuanian state budget expenditure on judiciary (in Eur per inhabitant) is one of the lowest in EU. Indeed, EU scoreboards do not cover analysis of disciplinary cases against judiciary, although in our opinion, it is an important criterion, which has direct impact to public trust in judiciary. Existing disciplinary system for infringements of legal ethics and prevention indicates that important steps are taken for transparency and intolerance of unethical behavior, but still there is place for improvements. Technologies play an important role in implementation of justice and are closely related with efficiency and quality of justice and are seen as positive instrument by judiciary leading to increased trust of society. Still there are risk factors as indicated by respondents which should be taken care in the nearest future. Arguably it is hard to create public confidence, but easy to lose it, because negative experience has a much more pronounced effect on citizen attitudes than good one. Just before submission of this paper to the journal, the public trust in judiciary in Lithuania was very seriously shattered by scandal of corruption of judges. As this case is still ongoing and final verdicts are not yet taken, we can only observe now that the levels of public trust felt almost twice and returned even to the lower level than five years ago. These facts only reaffirm the arguments regarding building and sustaining public trust elaborated in this paper.

Opinion about the institution depends not only on our personal experience, because only less than $10 \%$ of population usually have any direct experience with the court, but also on other sources, especially mass media. Therefore, it is crucial clearly highlight judicial professionalism and performance-based explanations, because even publications about public trust rates can really affect society's attitudes. Opinion leaders and power holders may play a central role in shaping public awareness about the judiciary. The level of democracy and scores of public trust in the state and other public institutions is a pivotal context, that can have a significant impact on the assessment of justice system. In Lithuania, the courts are still among the lowest trust scores having institutions together with political parties, parliament and government. Contingency between high political savvy level and confidence in the judiciary are only in advanced democracies, because more informed people seem to notice the failures and chronic systemic problems of justice system.

\section{References}

BAUMEISTER, Roy, F, BRATSLAVSKY, Ellen, FINKENAUER, Catrin, VOHS, Kathleen, D. Bad Is Stronger than Good. Review of General Psychology, 2001, vol. 5, no. 4, pp. 323-70. BRUNALAS, Benas. Naujausios Apklausos: Rekordinis Pasitikejimas Teismais [Latest Surveys: Record Trust in Courts]. [online]. Available at: <https://www.delfilt/a/78638041> Accessed: 23.08.2018

BÜHLMANN, Mark, KUNZ, Ruth. Confidence in the Judiciary: Comparing the Independence and Legitimacy of Judicial Systems. West European Politics, 2011, vol. 34, no. 2, pp. 317-345.

ÇAKIR, Aylin, Aydin, ŞEKERCIOĞLU, Eser. Public Confidence in the Judiciary: The Interaction between Political Awareness and Level of Democracy. Democratization, 2015, vol. 23, no. 4, pp. 634-656. 
CARRINGTON, Paul, D. Butterfly Effects: The Possibilities of Law Teaching in a Democracy. Duke Law Journal, 1992, vol.41, no. 4, pp. 741-805.

CURTIN, Deirdre, MEIJER, Albert, Jacob. Does Transparency Strengthen Legitimacy? Information Polity, 2006, vol. 11, no. 2, pp. 109-122.

DOBRYNINAS, Aleksandras, DRAKŠIENĖ, Anna, GAIDYS, Vladas, VILEIKIENĖ, Eglè. Pasitikejjimo Lietuvos Teisèsauga Profiliai [Profiles of Trust in Lithuanian Law Enforcement]. Vilnius: Vilnius University Press, 2012.

EGONDA-NTENDE, Frederick. The Role of Information Technology in Modernising the Courts. [online]. Presented to a Conference of the Southern African Judges Commission, Uganda, 3-6 February, 2005. Available at: <http://www.venice.coe.int/ SACJF/2005_02_UGA_Entebbe/Rep_Egonda_Ntende.htm> Accessed: 08.07.2018.

FISCHER, Dirk-Hinnerk. Making a Mark-Time Changing Politics from Estonia: An Alternative Idea for the British, Bulgarian and Estonian EU Presidency. Baltic Journal of European Studies, 2016, Vol. 6, No. 1, pp. 175-191.

GAIDYS, Vladas. Sociologas: atsistatyti gyventoju pasitikejimui teismais užtruks, [Sociologist: It will take time to restore the confidence of the people in the courts]. [online]. Available at: <https://www.15min.lt/naujiena/aktualu/lietuva/sociologas-atsistatytigyventoju-pasitikejimui-teismais-uztruks-56-1133674> Accessed 08.07.2019.

GIBSON, James, L. CALDEIRA, Gregory, A. Citizens, courts, and confirmations: Positivity theory and the judgments of the American people. Princeton: Princeton University Press, 2009.

GRIMMELIKHUIJSEN, Stephan, KLIJN, Albert. The effects of judicial transparency on public trust: evidence from a field experiment: effects of judicial transparency on public trust. Public Administration, 2015, vol. 93, no. 4, pp. 995-1011.

GRUODYTĖ, Edita, BERKMANAS, Tomas, KIRŠIENĖ, Julija, KIRCHNER, Stefan, GERVIENĖ, Silvija, SZYMANSKI, Charles, F., ŽIŽIENĖ, Simona, VERŠINSKAS, Tomas, MALINAUSKAS, Vygantas. Teisininkų etika: nuo status quo pavyzdinio modelio link [Legal ethics: from status quo towards exemplary model]. Monograph. Vytautas Magnus University: Vytautas Magnus University Press, 2016.

GRUODYTÉ, Edita. The disciplinary liability of Lithuanian lawyers: a comparative approach. Baltic Journal of Law \& Politics, 2014, vol. 7, no. 2, pp. 1-36.

HOUGH, Mike, SATO, Mai (ed.) Trust in Justice: Why It Is Important for Criminal Policy, and How It Can Be Measured. [online]. Available at: <https://www.heuni.fi/material/ attachments/heuni/reports/6KnfuLmJb/Text_pages_1-47.pdf> Accessed: 05.03.2019.

KIRŠIENĖ, Julija. Trimate teisininko profesijos krizès problema [The crisis of legal profession as three-dimensional problem]. Jurisprudencija, 2015, vol. 22, no. 2, pp. 191-205.

LICHT, Jenny de Fine. Do We Really Want to Know? The Potentially Negative Effect of Transparency in Decision Making on Perceived Legitimacy. Scandinavian Political Studies, 2011, vol. 34, no. 3, pp. 183-201.

MARTIN, Gary. There Are Three Kinds of Lies: Lies, Damned Lies, and Statistics - the Meaning and Origin of This Phrase. [online]. Available at: <https://www.phrases.org.uk/ meanings/lies-damned-lies-and-statistics.html.> Accessed: 16.12.2018.

NAIS, Acquaviva, FLORENCE, Castagnet, MORGANE, Evanghelou. A comparative analysis of disciplinary systems for European judges and prosecutors. [online]. Available at: $<\mathrm{http}: / /$ www.ejtn.eu/Documents/Themis\%202012/THEMIS\%202012\%20ERFURT\%20DOCUMENT/Written\%20paper\%20France\%203.pdf> Accessed: 16.02.2019.

Naujausia apklausa: šalies gyventojai labiausiai pasitiki ugniagesiais gelbetojais [The latest survey: The country's residents rely most on firefighters] [online]. Available at: $<\mathrm{http} / / /$ 
kauno.diena.lt/naujienos/lietuva/salies-pulsas/naujausia-apklausa-salies-gyventojailabiausiai-pasitiki-ugniagesiais-gelbetojais-877165> Accessed: 01.03.2019.

NORKŪNAS, Algis, GUTAUSKAS, Aurelijus,VALYTĖ, Toma, PAULIUKAITĖ, Aurelija. (2017) Lietuvos Respublikos teisejju etikos kodeksas - praktinis vadovas [Code of ethics of the judges of the Republic of Lithuania- Practical guide] [online]. Available at: <https:// www.teismai.lt/data/public/uploads/2017/09/tek-praktinis-vadovas-2017-09-29.pdf> Accessed: 21.02. 2019.

PETERS, Timothy, CRAWLEY, Karen. (ed.) Envisioning Legality: Law, Culture and Representation. UK: Routledge, 2017.

RAIŠIENE, Agota, Giedre, JONUŠAUSKAS, Steponas. Informacinių ir komunikacinių technologijų itaka darbuotojų technostresui: situacijos Lietuvoje charakteristika [Influence of information and communication technologies on employee technostress: situation in Lithuanian organizations]. INFORMACIJOS MOKSLAI, 2013, vol. 66, pp. 78-95.

REILING, Dory. Technology for justice. How information technology can support judicial reform. Dissertation. Leiden: Leiden university press, 2009.

REUTERS. Lithuania Arrests Eight Top Judges in Anti-Corruption Crackdown. [online]. Available at: <https://www.reuters.com/article/us-lithuania-corruption-idUSKCN1Q922O > Accessed 20.06.2019.

ROSA, Joao, TEIXEIRA, Claudio, PINTO, Joaquim, Sousa. Risk factors in e-justice information systems. Government Information Quarterly, 2013, vol. 30, issue 3, pp. 241-256.

RUZGYTĖ, Eglè. Teisininko profesija ir etika: riba tarp teisès ir moralès [The legal profession and ethics: the line Between law and morality]. Parlamento studijos, 2017, vol. 23, pp. $122-153$.

SCHROEDER, Werner. The EU Founding Values - Constitutional Character and Legal Implications. EUROPEAN STUDIES, 2016, vol. 3, pp. 50-64.

SCHWAB, Klaus. (Ed) The Global Competitiveness Report 2016-2017: insight report. [online]. Available at: <http://www3.weforum.org/docs/GCR2016-2017/05FullReport/ TheGlobalCompetitivenessReport2016-2017_FINAL.pdf> Accessed: 24.11.2018.

TYLER, Tom, R. Public Trust and Confidence in Legal Authorities: What Do Majority and Minority Group Members Want from the Law and Legal Institutions? Behavioral Sciences \& the Law, 2001, vol. 19, no. 2, pp. 215-235.

TYLER, Tom, R. Why People Obey The Law. Princeton: Princeton University Press, 2006.

VAIČELIŪNAITÉ, Gabija. A. Dobryninas: Apie Pasitikèjima Teismais Ir Požiūrị i Valstybe [A.Dobryninas. About Trust in Justice and Attitude to the State]. [online]. Available at: $<$ https://www.delfi.lt/a/76660913> Accessed 23.08.2018.

VILMORUS, 2018. Available at: <http://www.vilmorus.lt/index.php? mact=News,cntnt01,d etail,0\&cntnt01articleid=2\&cntnt01 returnid=20> Accessed: 23.11. 2018.

VILMORUS, 2019. Available at:<http://www.vilmorus.lt/index.php?mact=News, cntnt01,de tail,0\&cntnt01 articleid=4\&cntnt01 returnid=20> Accessed: 23.02 .2019$.

WELCH, Eric, W., HINNANT, Charles, C., MOON, Jae, M. Linking Citizen Satisfaction with E-Government and Trust in Government, Journal of Public Administration Research \& Theory, 2005, vol. 15, no. 3, pp. 371-391. 